\title{
AGENDA SETTING DALAM \\ PROSES PEMBENTUKAN KABUPATEN BANDUNG BARAT
}

\author{
Maman \\ Dede Sri Kartini \\ Neneng Yani Yuningsih \\ Program Studi Ilmu Pemerintahan Fakultas Ilmu Sosial \\ dan Ilmu Politik (FISIP) Universitas Padjadjaran \\ Email: \\ maman.42mn@gmail.com \\ dedekartini@yahoo.com \\ nenengyany@yahoo.co.id
}

\begin{abstract}
ABSTRAK
Penelitian ini dilatarbelakangi oleh terjadinya pemekaran di Kabupaten Bandung yaitu lahirnya Kabupaten Bandung Barat melalui Undang-Undang nomor 12 tahun 2007 Tentang Pembentukan Kabupaten Bandung Barat, dimana proses lahirnya Kabupaten Bandung Barat tak lepas dari proses politik dan juga isu subjektif yang senantiasa mewarnai proses pemekaran. Isu subjektif berupa kepentingan elit politik, pemilik modal dan juga birokrasi senantiasa menjadi isu yang bergulir selama pemekaran ini terjadi dan lebih menarik dibanding isu objektif pemekaran itu sendiri. Dalam proses pembentukan Kabupaten Bandung Barat pada tahun 2007, terdapat agenda setting yang dilakukan oleh beberapa aktor yang terlibat dalam proses pembentukannya. Aktor tersebut bukan hanya aktor pemerintah saja, namun juga melibatkan aktor LSM, pengusaha, media dan juga masyarakat pada umumnya yang memiliki kepentingan dalam pemekaran ini. Isu subjektif seperti kepentingan kekuasaan dan juga birokrasi tentu ada dalam proses pemekaran dan menambah dinamika dalam proses pemekaran
\end{abstract}

Kata Kunci: Agenda Setting, Pemekaran Daerah, Isu, Aktor, Kepentingan.

\section{ABSTRACT}

This research was motivated by the expansion of Bandung district, which created the West Bandung District based on the Constitution number 12, year 2007 
about the Establishment of West Bandung district, which the expansion process itself could not be separated from political process and also subjective issues that always interfered along the way. The subjective issues such as political elite interests, the owners of capital and the bureaucracy have always been a rolling issues during the expansion process and became more interesting than the objective issue of the expansion itself. In the creating process of West Bandung district in 2007, there was an agenda setting which conducted by some of the actors who involved in the formation. The actors were not only from the government, but also from the NGO (non-governmental organizations), businessmen, media and society who had concerns in the expansion in general. The subjective issues, such as the power interests and bureaucracy certainly existed in the expansion process and added the dynamics in it.

Keywords: Agenda Setting, Regional Expansion, Issues, Actors, Interests.

\section{PENDAHULUAN}

Format desentralisasi dalam Pemerintahan Indonesia yang sekarang ini diterapkan memungkinkan pemerintah daerah lebih efektif dalam memberikan pelayanan kepada masyarakat. Hal ini karena pemerintah daerah memiliki peranan lebih besar dan lebih strategis dalam melaksanakan pembangunan, termasuk menampung aspirasi masyarakat sebagai bahan dalam melaksanakan rencana pembangunan di daerah. Dengan diterapkannya sistem desentralisasi, maka diharapkan akan meningkatkan efektifitas pemerintahan.

Seiring dengan meningkatnya kebutuhan masyarakat akan pelayanan pemerintahan, serta desentralisasi yang memberikan peluang lebar bagi masyarakat di daerah untuk mengaspirasikan suaranya, hal tersebut melahirkan banyak tuntutan dari masyarakat di daerah. Salah satu tuntutan yang banyak bergulir pasca reformasi di Indonesia adalah adanya pemekaran wilayah, baik ditingkat provinsi maupun ditingkat daerah kabupaten atau kota.

Pemekaran daerah yang diaspirasikan oleh masyarakat, pada kenyataannya menjadi tuntutan yang rasional. Hal ini karena pada dasarnya bertujuan untuk memperkuat peran pemerintah dalam pelayanan dan juga pembangunan, termasuk pengelolaan daerah, sehingga diharapkan dapat tercapainya efisiensi, efektivitas dalam penyelenggaraan pemerintahan serta kesejahteraan masyarakat di daerah. Namun pada kenyataannya pemekaran daerah tidak selalu menjadikan pembangunan dan pelayanan di daerah tersebut berjalan dengan efektif, tapi justru berjalan tersendat dan banyak melahirkan masalah. Bahkan disatu sisi, pemekaran daerah 
hanyalah menjadi sebuah agenda dari elit-elit pemerintahan untuk membentuk dan mempertahankan kekuasaan yang pada jangka panjang memungkinkan untuk terbentuknya dinasti politik.

Pemekaran daerah yang sejak awal dilakukan untuk mengakomodir aspirasi masyarakat akan tuntutan mereka untuk meningkatkan kesejahteraan, pada kenyataannya tidak berjalan sesuai dengan apa yang diinginkan, bahkan pada beberapa kasus cenderung menimbulkan masalah tersendiri. Selain banyaknya daerah pemekaran yang memiliki kualitas buruk dalam pelayanan publik, pemekaran daerah juga menimbulkan konflik dan kekerasan di daerah yang akan dimekarkan.

Salah satu daerah otonom di Provinsi Jawa Barat yang baru dimekarkan adalah Kabupaten Bandung, yaitu dengan dibentuknya Kabupaten Bandung Barat. Pembentukan Kabupaten Bandung Barat pada Tahun 2007 memang dirasa wajar, mengingat Kabupaten Bandung yang memiliki luas sekitar 2.324.84 KM2, dengan penduduk sekitar 4,3 juta jiwa pada tahun 2002 pada kenyataannya membuat pemerintah tidak efektif dalam melaksanakan pelayanan dan pembangunannya. Kondisi inilah yang melatarbelakangi adanya keinginan masyarakat Bandung Barat untuk melakukan pemekaran Kabupaten Bandung.
Sementara itu ketika usulan pembentukan Kabupaten Bandung Barat diterima, Pemerintah Kabupaten Bandung langsung membentuk tim untuk mengkaji kelayakan pembentukan tersebut dengan mengundang konsorsium yang terdiri dari beberapa perguruan tinggi negeri dan swasta di Bandung. Tim konsorsium tersebut terdiri dari Unpad, ITB, IPDN, UPI, Unpas dan Unjani. Setelah itu, pemerintah juga membentuk tim teknis untuk penataan wilayah Kabupaten Bandung Barat yang langsung diketuai oleh Abu Bakar yang pada saat itu menjabat sebagai Sekretaris Daerah Kabupaten Bandung dan kini menjadi Bupati Bandung Barat selama dua periode jabatan. Setelah menjalani proses yang panjang, maka pada akhirnya Kabupaten Bandung Barat resmi terbentuk pada tahun 2007.

Dalam proses pembentukannya, melibatkan banyak aktor diantaranya keterlibatan LSM, media massa dan juga adanya tim pelaksana teknis lapangan dalam proses pembentukan Daerah Otonom Kabupaten Bandung Barat yang langsung diambil alih oleh jajaran Pemerintah Kabupaten Bandung, dan diketuai langsung oleh Sekretaris Daerah. Maka, tidak dipungkiri bahwa ada agenda politik elit pemerintahan di Kabupaten Bandung dalam proses pembentukan daerah otonom Kabupaten Bandung Barat.

Salah satu kecenderungan adanya agenda setting adalah ketika Abu 
Bakar yang pada saat proses pembentukan Kabupaten Bandung Barat menjadi Ketua Tim Teknis Penataan Wilayah Kabupaten Bandung Barat, sesudah terbentuknya Kabupaten Bandung Barat Abu Bakar menjadi Bupati pertama di Kabupaten Bandung Barat. Kemudian memenangkan pemilihan Bupati kembali untuk periode yang kedua, sehingga ia memegang kekuasaan di Kabupaten Bandung Barat dari tahun 2008 sampai tahun 2013 dan periode kedua dari tahun 2013 sampai dengan 2018. Hal ini tentunya menjadi prestasi politik bagi Abu Bakar dan juga partai politik pendukung yaitu PDIP di daerah otonom yang masih baru tersebut.

Selain itu adanya kepentingan dalam pembentukan wilayah dan pemerintahan Kabupaten Bandung Barat, juga bisa diamati dari pergerakan yang dilakukan oleh KPKBB. KPKBB berhasil menghimpun semua elemen LSM di Kabupaten Bandung untuk menyuarakan aspirasi terkait pemekaran. Terjadinya beberapa demonstrasi yang melibatkan massa dalam jumlah besar juga berhasil diinisiasi oleh KPKBB, diantaranya adalah unjuk rasa yang melibatkan 1000 warga dengan mendatangi Bupati Bandung Obar Sobarna pada Januari $2004^{42}$ dan juga untuk rasa 5000 warga di Kantor Pemkab Bandung untuk menuntut Obar Sobarna menandatangani nota pendirian Kabupaten Bandung Barat ${ }^{43}$

Keterlibatan media massa dalam proses pembentukan Kabupaten Bandung Barat juga dinilai cukup massif dan memiliki keberpihakan (Ade Atmaja 2006:10), hal ini bisa kita lihat dari beberapa surat kabar regional dimana ada banyak berita yang dimuat yang kecenderungan mendukung dilakukannya pemekaran dengan mengambil narasumber dari aktor-aktor politik dan pemerintahan di Jawa Barat. Beberapa media massa tersebut antara lain Pikiran Rakyat, Galamedia, Tribun Jabar dan Berita Pasundan. Beberapa berita yang diangkat antara lain adalah berita tentang aksi unjukrasa dan juga pernyataan tokoh yang mendukung pemekaran. Melihat gambaran tersebut, kajian ini akan melakukan penelusuran terhadap bagaimana agenda setting dalam proses pembentukan Kabupaten Bandung Barat pada Tahun 2007.

Dari uraian diatas, maka dilakukan identifikasi masalah sebagai berikut:

42. Galamedia, terbit Rabu 7 Januari 2004.

43. Berita Pasundan, Nomor 24, Tahun ke IV, terbit 12-19 Januari 2004. 
1. Bagaimana agenda setting dalam proses pembentukan Kabupaten Bandung Barat tahun 2007?

2. Bagaimana peran aktor yang terlibat dalam agenda setting pembentukan Kabupaten Bandung Barat tahun 2007?

\section{KERANGKA TEORETIS}

Pemekaran daerah menurut Undang-Undang No 23 Tahun 2014 Tentang Pemerintahan Daerah ${ }^{44}$ terdiri dari dua poin yaitu sebagai berikut:

a. Pemecahan daerah provinsi atau daerah kabupaten/kota untuk menjadi dua atau lebih daerah baru.

b. Penggabungan bagian daerah dari daerah yang bersanding dalam satu daerah provinsi menjadi satu daerah baru.

Pemekaran wilayah secara esensial bertujuan unt ukmeningkatkan kesejahteraan masyarakat di daerah. Hal ini karena dengan adanya pemekaran wilayah, maka diharapkan pelayanan dan juga program pembangunan akan terlaksana dengan lebih optimal, pemerintahan daerah akan lebih mampu dan optimal dalam menyentuh masyarakat secara kese- luruhan karena kemampuan mereka akan disesuaikan dengan luas wilayah yang mereka kuasai. Siswanto Sunanro dalam bukunya yang berjudul 'Hukum Pemerintahan Daerah di Indonesia', menjelaskan sebagai berikut:

"Secara filosofis bahwa tujuan pemekaran ada dua kepentingan, yakni pendekatan pelayanan umum pemerintahan kepada masyarakat dan yang kedua adalah untuk peningkatan kesejahteraan masyarakat setempat. Secara politis, kehendak tersebut harus didasarkan atas kemauan atau aspirasi masyarakat setempat yang diajukan kepada pemerintahan daerah setempat yakni pemerintah daerah dan DPRD.

Prof. Drs. HAW Widjaja menjelaskan tentang tujuan pemekaran daerah dengan tujuan untuk meningkatkan kesejahteraan masyarakat, hal ini sebagaimana dijelaskan oleh Prof. Drs. HAW Widjaja yang menjelaskan sebagai berikut

"Pembentukan daerah pada dasarnya ditujukan untuk meningkatkan pelayanan publik guna mempercepat terwujudnya kesejahteraan masyarakat disam-

44. Undang-Undang No 23 Tahun 2014 Tentang Pemerintahan Daerah, bab XI Tentang Penataan Daerah Bagian Dua Tentang Pembentukan Wilayah Pada Paragraf 1 Pasal 33 Ayat 1 Dan Dua. 
ping sebagai sarana pendidikan politik di tingkat lokal. Untuk itu maka pembentukan daerah harus mempertimbangkan berbagai faktor seperti: kemampuan ekonomi, luas wilayah dengan pertimbangan dari aspek sosial budaya, sosial politik dan pertahanan serta keamanan"45.

Salah satu daerah yang telah dimekarkan adalah Kabupaten Bandung yaitu dibentuknya Kabupaten Bandung Barat. Ade Ratmaja menjelaskan dalam bukunya yang berjudul 'Perjalanan pembentukan Kabupaten Bandung Barat' menjelaskan tentang latar belakang pembentukan Kabupaten Bandung Barat.

"Isu pemekaran ini pada awalnya dilandasi oleh adanya ketidakoptimalan pemerintahan Kabupaten Bandung dalam menjalankan tugas dan fungsinya seperti pelayanan publik, timpangnya kesejahteraan masyarakat di Kabupaten Bandung bagian Barat, serta timpangnya pembangunan di wilayah Kabupaten Bandung bagian Barat pada saat itu, hal ini bisa dilihat dari beberapa segi salah satunya adalah infrastruktur yang banyak mengalami kerusakan dan tidak mendapatkan program pembangunan yang memadai." ${ }^{46}$

Dengan adanya faktor-faktor tersebut maka munculah inisiasi untuk dilakukannya pembentukan Kabupaten Bandung Barat. Ketika isu ini muncul kembali pada tahun 1999, maka sudah mulai dibentuk forumforum untuk membahas wacana pemekaran tersebut, namun sempat tertunda akibat dilakukannya peningkatan status Kota Cimahi dari Kota Administratif menjadi Kota Cimahi. Pasca Kota Cimahi resmi menjadi Kota, maka isu pembentukan wilayah Kabupaten Bandung Barat muncul kembali dengan berbagai agenda setting yang terjadi dari beberapa elemen yang terlibat dan berkepentingan dalam pembentukan tersebut termasuk Pemerintahan Kabupaten Bandung.

Joko Widodo dalam bukunya yang berjudul 'Analisis Kebijakan Publik' (2009:53) menjelaskan bahwa "Agenda setting merupakan kegiatan

45. Prof. Dr. HAW. Widjaja. Otonomi Desa merupakan otonomi asli, bulat dan utuh. PT.RajaGrafindo Persada, Jakarta. Tahun 2005, hal 135

46. Ade Ratmaja., dkk. Perjalanan Pembentukan Kabupaten Bandung Barat Menjadi Daerah Otonom Di Provinsi Jawa Barat. Bandung Barat. Komite Pembentukan Kabupaten Bandung Barat (KPKBB).. tahun 2006 
membuat masalah publik menjadi masalah kebijakan" ${ }^{47}$.

Hal diatas sesuai dengan yang dikatakan oleh Jones bahwa "agenda adalah suatu istilah yang pada umumnya digunakan untuk menggambarkan suatu isu yang dinilai publik perlu diambil suatu tindakan". Penjelasan dari definisi diatas mempunyai makna yang sama dengan agenda kebijakan dimana agenda kebijakan adalah kegiatan yang dilakukan untuk membuat suatu permasalahan menjadi permasalahan publik yang bertujuan untuk melahirkan suatu kebijakan.

Oleh sebab itu dapat dikatakan bahwa yang dimaksud dengan agenda setting adalah bagaimana membentuk opini publik terhadap suatu persoalan sehingga persoalan tersebut dianggap sebagai suatu permasalahan penting bagi masyarakat luas termasuk bagi pemerintah. Dengan terbentuknya opini publik maka hal ini akan mendorong lahirnya kebijakan publik atau output yang diharapkan dari orang yang merancang setting tersebut.

Agenda setting atau agenda permasalahan ini kemudian akan berlanjut pada fase-fase selanjutnya termasuk memunculkan alternatif kebijakan dan menentukan kebijakan yang diambil. Dalam setiap fase, aktor pemilik kepentingan tentu melakukan usaha-usaha untuk mempengaruhi setiap kebijakan publik yang akan disusun. Setidaknya ada tiga hal yang dilakukan oleh aktor kepentingan untuk melakukan agenda setting; pertama membangun persepsi dikalangan stakeholders bahwa sebuah fenomena benar-benar dianggap sebagai masalah, kedua membuat batasan masalah, dan ketiga memobilisasi dukungan agar masalah tersebut masuk dalam agenda pemerintah. Sehingga dari berbagai usaha yang dilakukan sebagai bagian dari agenda setting aktor-aktor yang berkepentingan mampu mempengaruhi kebijakan publik.

Proses penyusunan agenda kebijakan (policy agenda) menurut Anderson, seperti di kutip Joko Widodo $^{48}$ bahwa secara beruntun terdiri dari beberapa tahapan berikut antara lain: private problems, public problems, issues, systemic agenda dan institutional agenda yang diuraikan sebagai berikut:

a. Privat problems, penyusunan agenda kebijakan diawali dari suatu masalah yang muncul di

47. Joko Widodo. Analisis Kebijakan Publik. Bayumedia: Malang. Tahun 2009: hal 53

48. Ibid; hal 53 
masyarakat, akan tetapi masalah tersebut diartikan sebagai suatu masalah pribadi atau tidak berdampak luas bagi masyarakat, masalah pribadi sendiri didefinisikan sebagai suatu masalah yang mempunyai akibat yang terbatas atau hanya menyangkut satu atau sejumlah kecil orang yang terlibat secara langsung.

b. Public problems, ketika masalah yang ada di masyarakat yang pada mulanya hanya sebagai privat problems terus bergulir dan melibatkan banyak orang, maka tahap selanjutnya privat problems tersebut berubah menjadi public problems. Public problems diartikan sebagai suatu masalah yang mempunyai akibat yang luas, termasuk akibat-akibat yang mengenai orang-orang yang terlibat secara tidak langsung.

c. Issues, ketika masalah yang ada dimasyarakat menjadi public problems, maka selanjutnya masuk pada tahap issues, issues diartikan sebagai problema publik yang saling bertentangan satu sama lain, artinya sudah terdapat suatu konflik. Issues dapat pula diartikan sebagai perbedaan-perbedaan pendapat yang ada dimasyarakat tentang persepsi dan solusi terhadap suatu masalah publik.

d. Systemic agenda, didefinisikan sebagai semua isu yang pada umumnya dirasakan oleh para anggota masyarakat politik yang patut mendapat perhatian publik dan isu tersebut memang berada dalam yurisdiksi kewenangan pemerintah.

e. Institutional agenda, didefinisikan sebagai serangkaian masalah yang secara tegas membutuhkan pertimbangan-pertimbangan yang aktif dan serius dari pembuat keputusan yang sah/otoritas.

Oleh sebab itu bisa disimpulkan bahwa agenda setting pada intinya berusaha untuk memunculkan masalah kepada publik sehingga publik menganggap penting terhadap suatu masalah yang sedang bergulir dimasyarakat dan dianggap sebagai suatu permasalahan yang membutuhkan tindakan kebijakan publik. Untuk membuat suatu masalah menjadi suatu masalah publik yang kemudian berakhir pada lahirnya kebijakan publik, tentu membutuhkan agenda setting untuk membangun opini dan menggerakan elemenelemen masyarakat atau aktor-aktor yang berkepentingan sehingga lahir kebijakan publik sebagai mana yang diharapkan.

Sementara itu, aktor dalam proses pembuatan kebijakan publik adalah orang yang mempunyai wewenang yang sah untuk ikut serta dalam formulasi hingga penetapan kebijakan publik. Walaupun dalam kenyataannya, beberapa aktor yang mempunyai wewenang sah untuk bertindak dikendalikan oleh orang lain seperti pimpinan parpol atau kelompok penekan. 
"Yang termasuk aktor dalam pembuat kebijakan secara normatif adalah lembaga legislatif, lembaga eksekutif, administrator, dan para hakim. Sementara itu juga terdapat kelompok atau aktor pembuat kebijakan yang ada diluar pemerintahan, beberapa kelompok aktor tersebut yaitu kelompok kepentingan, partai politik dan warga negara sebagai indivudu." 49

Berdasarkan kerangka pemikiran yang telah disusun, maka untuk memudahkan memahami peta konsep penelitian, peneliti akan mencoba menjelaskan secara lebih sederhana dalam model penelitian sebagai berikut:
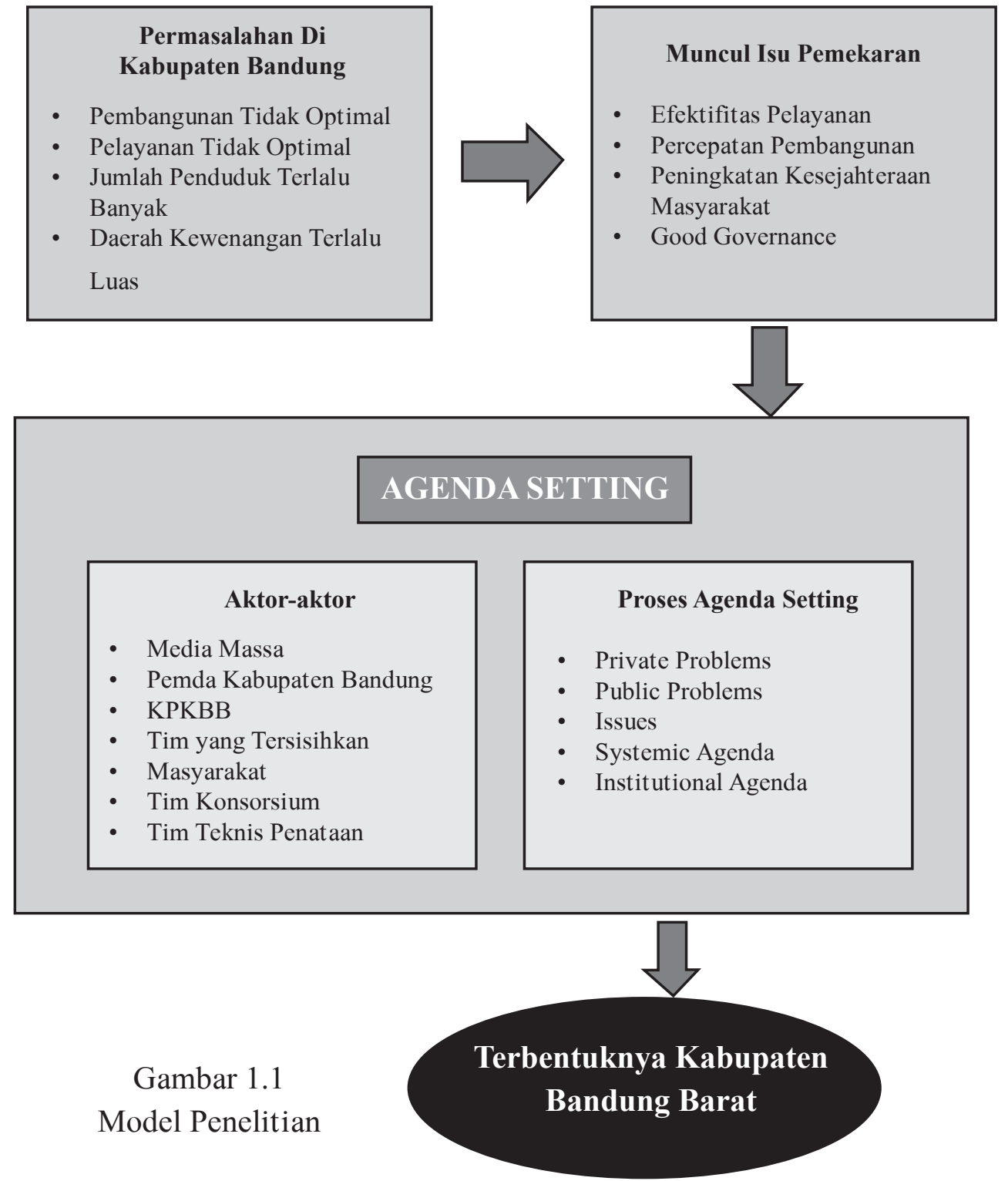

49. Leo Agustino. Dasar-dasar Kebijakan Publik. Alfabetas. Bandung. Tahun 2008: hal 39 


\section{METODE PENELITIAN}

Metode kualitatif sebagai salah satu prosedur dalam penelitian yaitu proses yang dilakukan dengan menghimpun data yang berasal dari berbagai sumber bisa dari narasumber, yaitu tokoh yang terlibat ataupun dari sumber lain seperti catatan yang menjelaskan objek yang kita teliti dan kemudian diolah serta disajikan dalam bentuk narasi. Narasi sebagai bentuk display data memberikan informasi yang menyeluruh tentang objek yang kita teliti. Oleh sebab itu, latar dan juga aktor yang terlibat dalam objek penelitian harus diposisikan secara menyeluruh, dalam artian tidak boleh memisahkan aktor yang ada sehingga informasi yang kita dapat tidak komprehensif. Hal tersebut sesuai dengan apa yang dijelaskan oleh Bogdan dan Taylor dalam buku yang ditulis oleh Lexi Moleong dengan judul Metodologi Penelitian Kualitatif, ia menjelaskan:

"Metodologi kualitatif adalah prosedur penelitian yang menghasilkan data deskriptif berupa kata-kata tertulis atau lisan dari orang-orang dan prilaku yang dapat diamati. Menurut mereka, pendekatan ini diarahkan pada latar dan individu tersebut secara holistik (utuh). Jadi dalam hal ini tidak boleh mengisolasikan individu atau organisasi ke dalam variabel atau hipotesis, tetapi perlu memandangnya sebagai bagian dari sesuatu keutuhan". ${ }^{50}$

Alasan peneliti menggunakan pendekatan kualitatif ini karena pendekatan kualitatif mudah disesuaikan dengan situasi yang akan peneliti hadapi. Peneliti berperan sebagai instrumen terpenting dan harus berperan aktif dalam proses penelitian di lapangan. Dalam penelitian ini peneliti akan menggunakan alat pengumpul data utama yang berupa ucapan, tulisan, gambar-gambar dan tidak menggunakan angka-angka. Tujuan penelitian kualitatif adalah untuk memahami situasi tertentu dan diarahkan pada kelompok masyarakat maupun lembaga secara menyeluruh.

Dalam proses pembentukan Kabupaten Bandung Barat, beberapa hal yang menarik muncul, seperti terlibatnya KPKBB yang begitu massif dari mulai menghimpun semua LSM di Kabupaten Bandung sampai dengan aksi besar-besaran. Selain itu fenomena dalam aspek politik dengan terpilihnya Abu Bakar sebagai bupati yang kemudian memenangkan kontes-

50. Lexi J. Moleong. Metodologi Penelitian Kualitatif. Remaja Rosda Karya, Bandung. Tahun 2007: hal 4 
tasi dua kali masa jabatan. Sehingga dengan penelitian kualitatif ini diharapkan dapat menafsirkan fenomena yang terjadi dalam proses pembentukan Kabupaten Bandung Barat.

Moleong sendiri dalam bukunya menyebutkan bahwa :

"Penelitian kualitatif itu berakar pada penelitian alamiah sebagai keutuhan, mengandalkan manusia sebagai alat penelitian, memanfaatkan metode kualitatif, mengadakan analisis data secara induktif, mengarahkan sasaran penelitiannya pada usaha menemukan teori dari-dasar, bersifat deskriptif, lebih mementingkan proses daripada hasil, membatasi studi dengan fokus, memiliki seperangkat kriteria untuk memeriksa keabsahan data, rancangan penelitiannya bersifat sementara, danhasilpenelitiannya disepakati oleh kedua belah pihak: peneliti dan subjek penelitian." 51

Ada beberapa teknik pengambilan data yang dapat dilakukan dalam melakukan penelitian kualitatif yaitu sebagai berikut: Studi Kepustakaan, Observasi dan Wawancara mendalam.

Dengan teknik pengumpulan data tersebut diatas, diharapkan penelitian mengenai Agenda Setting Dalam Proses Pembentukan Kabupaten Bandung Barat Tahun 2007 menjadi daerah otonom Kabupaten Bandung Barat akan mendapatkan data yang lengkap meliputi data yang sudah diarsipkan dalam berbagai bentuk termasuk data yang diambil dari aktor-aktor yang terlibat secara langsung dan mengetahui seluk belum dinamika proses pembentukan Kabupaten Bandung Barat sebagai daerah otonom baru.

Tabel 1.2 Daftar Informan

\begin{tabular}{|c|c|c|c|}
\hline No & Informan & Jabatan & Informasi yang Ingin di Dapatkan \\
\hline 1 & $\begin{array}{l}\text { Drs. H. Endang } \\
\text { Anwar }\end{array}$ & $\begin{array}{l}\text { Ketua umum } \\
\text { KPKBB }\end{array}$ & $\begin{array}{ll}\checkmark & \text { Peran KPBB dalam pembentukan } \\
& \text { Kabupaten Bandung Barat } \\
\checkmark & \text { Kepentingan KPKBB dalam } \\
\text { pembentukan Kabupaten Bandung } \\
\text { Barat } \\
\checkmark & \text { Dinamika kepentingan dalam proses } \\
\text { pembentukan Kabupaten Bandung } \\
\text { Barat } \\
\checkmark & \text { Komunikasi dari dan kepada } \\
\text { KPKBB dalam proses pembentukan } \\
\text { Kabupaten Bandung Barat }\end{array}$ \\
\hline
\end{tabular}

51. Ibid. hal 5 


\begin{tabular}{|c|c|c|c|}
\hline 2 & Drs. H. Agus Yasmin & $\begin{array}{l}\text { Ketua DPRD } \\
\text { Kabupaten } \\
\text { Bandung periode } \\
20042009\end{array}$ & $\begin{array}{ll}\checkmark & \text { Peran DPRD Kabupaten Bandung } \\
\text { dalam proses pembentukan } \\
\text { Kabupaten Bandung Barat } \\
\checkmark & \text { Strategi yang dilakukan oleh DPRD } \\
\text { untuk merespon aspirasi masyarakat } \\
\text { terkait pemekaran. } \\
\checkmark & \begin{array}{l}\text { Isu subjektif yang berkembang } \\
\text { terkait pembentukan Kabupaten } \\
\text { Bandung Barat }\end{array}\end{array}$ \\
\hline 3 & $\begin{array}{l}\text { H. Obar Sobarna } \\
\text { S.IP }\end{array}$ & $\begin{array}{l}\text { Mantan Bupati } \\
\text { Bandung }\end{array}$ & $\begin{array}{ll}\checkmark & \text { Peran H. Obar Sobarna S.Ip dalam } \\
& \text { pemekaran H. Obar Sobarna S.Ip } \\
\checkmark & \text { Dinamika kepentingan dalam proses } \\
& \text { pemekaran H. Obar Sobarna S.Ip } \\
\checkmark & \text { Bentuk intervensi atau desakan } \\
\text { kepentingan yang terjadi selama } \\
\text { proses pembentukan KBB. }\end{array}$ \\
\hline 4 & Tokoh masyarakat & $\begin{array}{l}\text { Budi Buntaran } \\
\text { (Kepala Desa } \\
\text { Cilangari pada } \\
\text { tahun 2003-2007) }\end{array}$ & $\begin{array}{ll}\checkmark & \text { Peran masyarakat dalam proses } \\
\text { pembentukan Kabuaten Bandung } \\
\text { Barat }\end{array}$ \\
\hline 5 & Drs. H. Abu Bakar & $\begin{array}{l}\text { Ketua tim teknis } \\
\text { penataan Wilayah } \\
\text { Kabupaten } \\
\text { Bandung sekaligus } \\
\text { sebagai Bupati } \\
\text { Bandung Barat } \\
\text { untuk dua kali masa } \\
\text { jabatan }\end{array}$ & $\begin{array}{ll}\checkmark & \text { Peran Drs. H. Abu Bakar terkait } \\
\text { posisi sebagai Ketua tim teknis } \\
\text { penataan Wilayah Kabupaten }\end{array}$ \\
\hline 6 & $\begin{array}{l}\text { H. Dede Mariana, } \\
\text { Drs., M.Si }\end{array}$ & $\begin{array}{l}\text { Tim Konsorsium } \\
\text { Perguruan Tinggi } \\
\text { Untuk Penataan } \\
\text { Wilayah Kabupaten } \\
\text { Bandung }\end{array}$ & $\begin{array}{ll}\checkmark & \text { Peran Tim Konsorsium dalam proses } \\
\text { pemekaran } \\
\checkmark & \text { Dinamika yang terjadi selama } \\
\text { penyusunan dan pengkajian } \\
\text { kelayakan pemekaran } \\
\checkmark & \begin{array}{l}\text { Evaluasi terhadap hasil pemekaran } \\
\text { pada saat sekarang }\end{array}\end{array}$ \\
\hline 7 & $\begin{array}{l}\text { Ormas ormas yang } \\
\text { terlibat }\end{array}$ & $\begin{array}{l}\text { LSM Pedang } \\
\text { di Kecamatan } \\
\text { Lembang }\end{array}$ & $\begin{array}{ll}\checkmark & \text { Peran ormas dalam proses } \\
& \text { pembentukan Kabupaten Bandung } \\
& \text { Barat } \\
\checkmark & \text { Sikap yang diambil oleh ormas } \\
& \text { secara umum } \\
\checkmark & \text { Strategi yang dilakukan oleh ormas } \\
\text { dalam mendukung atau menolak } \\
\text { pemekaran } \\
\checkmark & \text { Bentuk intervensi yang dilakukan } \\
& \text { oleh elit kepentingan } \\
\checkmark & \text { Dampak dari pemekaran } \\
\text { terhadap kualitas pelayanan dan } \\
\text { pembangunan pada saat ini }\end{array}$ \\
\hline
\end{tabular}




\begin{tabular}{|c|c|c|c|}
\hline 8 & $\begin{array}{l}\text { Masyarakat umum } \\
\text { yang memahami } \\
\text { pembentukan } \\
\text { Kabupaten Bandung } \\
\text { Barat }\end{array}$ & & $\begin{array}{ll}\checkmark & \text { Bentuk intervensi yang dilakukan } \\
\text { oleh elit kepentingan } \\
\checkmark & \text { Dampak dari pemekaran } \\
\text { terhadap kualitas pelayanan dan } \\
\text { pembangunan pada saat ini }\end{array}$ \\
\hline 9 & $\begin{array}{l}\text { Pihak yang tidak } \\
\text { menyetujui } \\
\text { pemekaran }\end{array}$ & $\begin{array}{l}\text { Forum } 14 \text { di } \\
\text { Kecamatan Cililin }\end{array}$ & $\begin{array}{ll}\checkmark & \text { Alasan tidak setuju terhadap } \\
\text { pemekaran }\end{array}$ \\
\hline 10 & Donny Widiaman & $\begin{array}{l}\text { Tim Perencana } \\
\text { pemekaran }\end{array}$ & $\checkmark \quad$ Mengetahui strategi dan tujuan \\
\hline 11 & Tjatja Kuswara & $\begin{array}{l}\text { Mantan Penjabat } \\
\text { Bupati Kabupaten } \\
\text { Bandung Barat }\end{array}$ & $\begin{array}{l}\checkmark \text { Untuk mengetahui kondisi } \\
\text { Kabupaten Bandung Barat pasca } \\
\text { terbentuk serta langkah yang } \\
\text { dilakukan oleh pemerintah dalam } \\
\text { mengawali proses pemerintahan }\end{array}$ \\
\hline
\end{tabular}

Pada penelitian ini analisis data dilakukan melalui langkah-langkah sebagai berikut: reduksi data, display data, pengambilan kesimpulan dan verifikasi.

\section{HASIL DAN PEMBAHASAN}

\section{Agenda Setting Dalam Proses Pembentukan Kabupaten Bandung Barat Tahun 2007}

Aspirasi pemekaran daerah otonom terjadi karena adanya berbagai permasalahan di masyarakat luas yang memicu ketidakpuasan masyarakat terhadap pemerintah dan menuntut untuk dicarikan solusi yang salah satunya adalah membentuk wilayah dan pemerintahan yang baru, dengan harapan akan tercipta kesejahteraan masyarakat karena peran pemerintah dirasa akan lebih efektif dan efisien sehingga fungsi-fungsi pemerintah seperti yang dijelaskan oleh Ryas Rasyid seperti pelayanan, pembangunan dan pemberdayaan bisa terlaksana dengan baik, ${ }^{52}$.

Berbagai masalah yang ada dimasyarakat Kabupaten Bandung yang memicu aspirasi pemekaran Kabupaten Bandung Barat pada

52. Ryaas Rasyid. Makna Pemerintahan: Tinjauan Dari Segi Etika Dan Kepemimpinan. Mutiara Sumber Widya. Jakarta:. Tahun 2000: hal 73. 
kenyataannya merupakan masalah yang berkaitan dengan kebutuhan dasar masyarakat seperti kurangnya pelayanan pemerintah terhadap kebutuhan masyarakat, pembangunan tidak optimal terutama infrastruktur seperti jalan raya, fasilitas kesehatan dan fasilitas pendidikan serta adanya kesenjangan pembangunan dan kesempatan masyarakat untuk mengakses fasilitas publik dan juga akses terhadap kesempatan ekonomi, sehingga menciptakan kecemburuan sosial di masyarakat.

Hal tersebut seperti yang diungkapkan oleh Dede Mariana ${ }^{53}$ yang menjelaskan sebagai berikut:

"Permasalahan yang ada di Kabupaten Bandung yaitu berkisar pada pelayanan dasar sosial, seperti pendidikan dan kesehatan yang tidak memenuhi terutama bisa ditemukan di daerah-daerah yang masih minim pembangunan, seperti rumah sakit di wilayah Bandung Barat yang hanya ada di Cililin dan baru mengalami perbaikan setelah dilakukan pemekaran daerah otonom, oleh sebab itu pemekaran menjadi salah satu pintu solusi terbaik untuk memperbaiki pelayanan publik"
Berbagai masalah tersebut menjadi amunisi bagi aktor-aktor yang terlibat aktif dalam memperjuangkan pembentukan daerah otonom baru untuk terus berusaha mencapai titik persetujuan bahwa suatu daerah harus dimekarkan dan dibentuk daerah baru, sehingga Kabupaten Bandung Barat secara resmi dibentuk pada tahun 2007.

Untuk membuat suatu masalah dijadikan bahan pertimbangan oleh pemerintah dalam perumusan kebijakan publik termasuk kebijakan pemekaran daerah, maka perlu disusun agenda setting yaitu suatu rangkaian proses yang dilakukan agar masalah bisa diketahui oleh publik secara luas dan mendapatkan perhatian dari pemerintah.

Seperti sudah dijelaskan bahwa agenda setting sebagai salah satu langkah proses perumusan kebijakan publik memiliki beberapa tahapan yang lebih detail yaitu individual problems, public problems, issues, systemic agenda dan institutional agenda. Namun sebelum membahas kelima tahapan tersebut, terlebih dahulu dijelaskan keterkaitan antara individual problems, dan public problems.

53. Wawancara dengan Dede Mariana yang merupakan Guru Besar Ilmu Pemerintahan. Pada saat proses pemekaran, Dede Mariana menjadi Ketua Tim Konsorsium 6 Perguruan Tinggi. 
Bahwa pengertian individual problems adalah masalah yang dirasakan oleh seseorang atau sebagian masyarakat saja dan tidak berdampak langsung terhadap masyarakat luas. Sementara itu pengertian dari public problems adalah suatu masalah yang dirasakan oleh masyarakat banyak dan memberikan pengaruh kepada masyarakat banyak baik yang terkait secara langsung maupun tidak langsung.

Akan tetapi pada dasarnya individual problems dan public problems tidaklah jauh berbeda bahkan sama. Misalnya individual problems terkait masalah pendidikan, sebagian masyarakat Bandung Barat merasa jarak untuk mengakses pendidikan yang jauh, sebagian merasakan fasilitas yang kurang memadai, pun hal yang sama dalam bidang kesehatan dan bidang lainnya seperti perdagangan. Maka ketika dikonfirmasi terkait masalah publik atau public problems, masalah yang muncul ternyata sama, yaitu masalah pendidikan, kesehatan dan lain sebagianya.

Jadi bisa disimpulkan, bahwa masalah publik atau public problems yang ada dimasyarakat cenderung sama, namun yang menjadikan adanya individual problems atau masalah bagi masing-masing individu adalah karena adanya perbedaan sudut pandang tiaptiap kelompok masyarakat dalam memandang masalah-masalah publik tersebut sehingga seolah terdapat berbagai varian masalah. Privat problems didefinisikan sebagai suatu masalah yang mempunyai akibat yang terbatas atau hanya menyangkut satu at au sejumlah kecil orang yang terlibat secara langsung, keberadaan masalah dirasa tidak menyebabkan dampak luas karena hanya dirasakan oleh sebagian masyarakat saja.

Masalah lain terkait proses pemekaran ini adalah permasalahan rentang kendali pemerintahan dan luas wilayah yang menghambat pemberian pelayanan oleh pemerintah daerah, Kabupaten Bandung memiliki daerah yang terlalu luas sehingga menyebabkan rendahnya rentang kendali pemerintah daerah yang menyebabkan kebutuhan dasar masyarakat tidak berhasil dipenuhi pemerintah.

Meskipun pemerintah sudah menangani masalah rentang kendali ini dengan cara melimpahkan beberapa kewenangan kepada kecamatan diantaranya adalah urusan administrasi umum, informasi, pemerintahan, ketertiban, pemeliharaan sarana umum, pemberdayaan dan pendapatan dae$\mathrm{rah}^{54}$, namun tetap saja kondisi yang

54. Keputusan Bupati Bandung Nomor 21 Tahun 2001 tentang Pelimpahan Kewenangan Kepada Pemerintah Kecamatan yang berjumlah 8 poin. 
ada dilapangan tidak tertangani dengan benar sehingga menyebabkan ketimpangan pembangunan terutama di daerah yang terpencil.

Dengan demikian bisa disimpulkan bahwa beberapa masalah yang dirasakan oleh sebagian masyarakat berkisar pada hal-hal fisik yang bermuara kepada rendahnya kualitas pembangunan dan pelayanan publik. Masalah-masalah tersebut antara lain perjalanan yang terhambat karena jalan raya yang rusak, jarak ke sekolah yang jauh sehingga banyak anak-anak enggan melanjutkan sekolah termasuk alasan biaya yang tinggi, serta sarana kesehatan yang jauh sehingga banyak masyarakat merasa tidak mampu menjangkau sarana kesehatan, hal ini membuat masyarakat kurang mendapatkan perhatian dalam bidang kesehatan secara memadai.

Sementara itu bagi orang-orang yang ada di lembaga pemerintahan, masalah yang mereka rasakan adalah rentang kendali yang rendah dikarenakan terlalu luasnya wilayah serta jarak yang harus ditempuh cukup jauh, ditambah dengan kondisi sarana yang menghambat seperti kerusakan jalan dan lain sebagainya. Permasalahan ini membuat pelayanan dan pembangunan tidak maksimal serta membuat biaya penyelenggaraan pemerintahan menjadi mahal.

Public problems atau masalah publik, diartikan sebagai suatu masalah yang mempunyai akibat yang luas, termasuk akibat-akibat yang mengenai orang-orang yang terlibat secara tidak langsung. Berdasarkan hasil pengkajian terhadap sumber data yang ada dilapangan baik data yang berasal dari dokumen, pengamatan secara langsung maupun wawancara terhadap informan, terdapat beberapa permasalahan publik yang ada di Kabupaten Bandung yang secara umum diakibatkan oleh terlalu luasnya wilayah kewenangan yang tidak dibarengi dengan kemampuan atau kapasitas Pemerintah Kabupaten Bandung.

\section{Issues, Muncul Isu Pembentukan Kabupaten Bandung Barat}

Issues diartikan sebagai perbedaan-perbedaan pendapat yang ada dimasyarakat tentang persepsi dan solusi terhadap suatu masalah publik. Bisa dikatakan bahwa dalam tahap ini, masyarakat sudah mengetahui dan merasakan semua permasalahan yang terjadi hanya saja masyarakat masih memilih-milih bentuk solusi yang seharusnya diambil. Perbedaan pandangan dan juga konflik menjadi dinamika tersendiri dalam fase ini berkaitan dengan penyelesaian terbaik yang seharusnya dilakukan oleh pemerintah.

Isu yang berkembang di masyarakat adalah isu pemekaran Kabupaten Bandung yaitu dibentuknya Kabupaten Bandung Barat. Persepsi masyarakat yang berkembang yaitu bahwa daerah Kabupaten Bandung dinilai terlalu luas dan tidak sebanding 
dengan kemampuan Pemerintah Kabupaten Bandung. Akibatnya penyelenggaraan tugas dan fungsi pemerintah menjadi tidak maksimal sehingga baik pelayanan masyarakat, pembangunan dan juga pemberdayaan tidak berjalan dengan baik.

Rentang kendali pemerintah yang selama ini dinilai masih rendah, menyebabkan tidak optimalnya tugas dan fungsi pemerintah serta menyebabkan beberapa permasalahan lainnya seperti tidak terpenuhinya kebutuhan dasar masyarakat dan juga menyebabkan ketimpangan pembangunan di beberapa daerah terutama di Kabupaten Bandung bagian barat. Maka menurut persepsi masyarakat, untuk menyelesaikan masalah ini adalah dengan melakukan pemekaran daerah sehingga kapasitas pemerintah disesuaikan dengan kondisi daerah kewenangan.

\section{Systemic Agenda, Menguatnya Isu Pembentukan Kabupaten Bandung Barat}

Systemic agenda, didefinisikan sebagai semua isu yang pada umumnya dirasakan oleh anggota masyarakat politik yang patut mendapat perhatian publik dan isu tersebut memang berada dalam yurisdiksi kewenangan pemerintah. Seperti sudah dijelaskan diatas bahwa masalah publik yang mengemuka di Kabupaten Bandung, jika dikelompokan dalam kelompok besar diantaranya adalah rendahnya rentang kendali pemerintah, pembangunan dan pelayanan yang tidak optimal serta timpangnya pembangunan di Kabupaten Bandung bagian barat, sehingga menyebabkan lahirnya kecemburuan sosial yang kemudian melahirkan inisiasi untuk melakukan pembentukan daerah otonom baru yaitu Kabupaten Bandung Barat.

Ketika berbagai permasalahan di Kabupaten Bandung sudah mengemuka dan menjadi perhatian masyarakat, pro kontra pun muncul menambah dinamika yang ada baik di level Pemerintah Kabupaten Bandung maupun dikalangan masyarakat, pro kontra terhadap solusi yang harus diambil untuk menyelesaikan masalah publik ini berbeda satu sama lainnya sehingga memakan waktu yang cukup lama. Hal ini tidak dipungkiri bahwa masing-masing pihak memiliki kepentingan berbeda terkait pembentukan Kabupaten Bandung Barat sehingga setiap aktor berusaha untuk mengusahakan tercapainya kepentingan mereka.

Kelompok yang menyetujui pembentukan KBB adalah kalangan LSM, partai politik, kalangan ulama dan berbagai lapisan tokoh masyarakat serta didukung oleh birokrat yang ada di wilayah Bandung Barat. Alasan mereka cukup jelas yaitu isu objektif yang ada dilapangan seperti luas daerah, ketimpangan pembangunan dan pelayanan, serta berbagai alasan lain yang menjadi masalah publik dimana kebutuhan dasar masyarakat di sebagian daerah dinilai tidak 
mampu dipenuhi oleh Pemerintah Daerah Kabupaten Bandung. ${ }^{55}$

LSM dan kelompok masyarakat lainnya di Kabupaten Bandung yang pada awalnya bergerak masingmasing seperti FORBES, FPBB dan berbagai LSM dilevel kecamatan, kemudian menyetujui dibentuknya komite yaitu KPKBB atau Komite Pembentukan Kabupaten Bandung Barat. Tujuan dibentuknya komite ini menurut Ade Ratmaja yang menjabat sebagai Sekretaris KPKBB, adalah untuk menyamakan visi misi mendukung percepatan dibentuknya KPKBB serta untuk menampung aspirasi semua kalangan masyarakat dan menghimpun kekuatan untuk mensukseskan pemekaran.

Bisa disimpulkan bahwa KPKBB sebagai sebuah komite yang menghimpun semua elemen masyarakat pendukung pembentukan Kabupaten Bandung Barat, melakukan berbagai upaya dalam mencapai terbentuknya Kabupaten Bandung Barat, upaya tersebut dilakukan dari mulai unjukrasa, deklarasi, rapat besama pemerintah dan DPRD, lobby dengan DPR-RI dan Pemerintah Pusat, hingga melakukan sosialisasi kepada masyarakat terkait upaya pembentukan Kabupaten Bandung Barat.

KPKBB yang dibentuk oleh LSM dan kelompok masyarakat yang mendukung pembentukan Kabupaten Bandung Barat pada kenyataannya terbentuk karena kepentingan aktor yang mengendalikan mereka dibelakang atau yang kita sebut dengan Tim yang Tersisihkan. Oleh karena itu sudah dipastikan bahwa KPKBB ini dalam geraknya disamping memperjuangkan pembentukan Kabupaten Bandung Barat, juga membawa kepentingan pribadi atau kelompok yang sudah tentu sejalan dengan keinginan pengusaha dan birokrat yang tergabung dalam Tim yang Tersisihkan tersebut.

KPKBB dalam gerakannya ternyata tidak bisa lepas dari kepentingan subjektif yang ingin dicapai oleh sebagian elit. Salah satu kepentingannya adalah pada saat Kabupaten Bandung Barat sudah resmi di bentuk, KPKBB kemudian merekomendasikan Panji Tirtayasa sebagai pjs Bupati Kabupaten Bandung Barat. Padahal saat itu Panji Tirtayasa sedang menjabat sebagai Kepala BAPPEDA Kota Serang,

55. Ade Ratmaja., dkk. Perjalanan Pembentukan Kabupaten Bandung Barat Menjadi Daerah Otonom Di Provinsi Jawa Barat. Bandung Barat. Komite Pembentukan Kabupaten Bandung Barat (KPKBB).. tahun 2006: hal 3. 
namun kenyataannya KPKBB cukup kuat merekomendasikan Panji untuk dijadikan pjs. Penunjukan Panji Tirtayasa dilandasi bahwa Panji merupakan orang yang tepat karena memiliki pengalaman yang luas serta pengetahuan yang cukup terkait Kabupaten Bandung Barat terlebih ia adalah putra daerah asli KBB yang lahir di Cipendeuy. ${ }^{56}$

Menjadi hal yang bertolak belakang ketika KPKBB merekomendasikan Panji Tirtayasa sebagai Pjs Bupati Bandung Barat dengan alasan Panji memiliki pengalaman yang luas dan pengetahuan yang cukup terkait KBB, sementara di satu sisi bahwa ada beberapa hal yang menyanggah argumentasi tersebut, antara lain bahwa pada saat yang bersamaan Panji Tirtayasa sedang menjadi pejabat di Kota Serang yaitu sebagai kepala Bappeda Kota Serang yang ditugaskan oleh Pemerintah Provinsi Jawa Barat. Di sisi lain, Kepindahan tempat tinggal Panji di Kota Cimahi cukup menjelaskan bahwa ia bukan lagi sebagai warga Kabupaten Bandung Barat.

Jadi berdasarkan fakta diatas seharusnya KPKBB lebih memprioritaskan orang lain yang memang sebagai tokoh atau penduduk Kabupaten Bandung Barat, dibandingkan dengan mencalonkan orang yang sedang menjabat di daerah lain dengan tempat tinggal secara administatif bukan di Kabupaten Bandung Barat.

\section{Institutional Agenda, Dinamika Pemerintah dan DPRD Terkait Pembentukan Kabupaten Bandung Barat}

Institutional agenda, didefinisikan sebagai serangkaian masalah yang secara tegas membutuhkan pertimbangan-pertimbangan yang aktif dan serius dari pembuat keputusan yang sah/otoritas. Pada tahap institutional agenda ini, isu yang muncul sudah mengerucut dan memberikan tekanan tertentu kepada pemerintah serta menjadi dinamika di kalangan otoritas yang berwenang, hal ini karena aktor-aktor yang berperan sudah melakukan tuntutan secara langsung kepada pemerintah untuk merealisasikan aspirasi yang dibawanya.

KPKBB menjadi aktor terdepan dalam mensukseskan pembentukan Kabupaten Bandung Barat dimana KPKBB menjadi himpunan semua aktor yang mendukung pemekaran, guna menekan pemerintah agar

56. Dikutip dari Koran Pikiran Rakyat dengan judul "KPKBB Usulkan Panji Pj Bupati Bandung Barat" halaman 9 terbit pada selasa 3 Oktober 2006. 
menyetujui pemekaran ini secepatnya. Sampai tahun 2004 tercatat beberapa kali dilakukan demonstrasi di depan Kantor Pemerintah Kabupaten Bandung yang dipimpin oleh KPKBB ini, dalam aksi tersebut massa terbanyak berjumlah sekitar 5000 orang yang berasal dari 15 kecamatan pendukung pemekaran ${ }^{57}$.

Besarnya tuntutan dari masyarakat terutama di wilayah Bandung Barat, serta dukungan mayoritas DPRD Kabupaten Bandung, maka wacana pembentukan Kabupaten Bandung Barat menjadi salah satu masalah atau isu yang mendapatkan respon dari pemerintah. Tindakan pertama yang dilakukan oleh pemerintah dalam merespon aspirasi pemekaran ini adalah dengan terbitnya Surat Keputusan Bupati No 135/ Kep.85-Binpenum/2004 tentang pembentukan Tim Teknis Penataan Wilayah Kabupaten Bandung, dimana berdasarkan hasil kajian bahwa pembentukan Kabupaten Bandung Barat layak untuk dilakukan.

Dalam perjalanan pembahasan pembentukan Kabupaten Bandung Barat ini, terjadi dinamika yang cukup dinamis baik di kalangan Legislatif maupun di kalangan Eksekutif. Terjadi pro dan kontra di kalangan pemerintah dan juga DPRD, namun yang menarik adalah ada rasionalisasi atau kepentingan yang melandasi penolakan pembentukan Kabupaten Bandung Barat ini, baik di pihak Pemerintah maupun di pihak DPRD. Kepentingan pribadi dan kepentingan kelompok adalah hal yang memang tidak terpisahkan dari sebuah keputusan menolak atau menyetujui pemekaran Kabupaten Bandung. Dalam tahap ini di lakukan analisis terhadap kepentingan masing-masing aktor pemerintah sebagai sebuah proses agenda setting dalam proses pembentukan Kabupaten Bandung Barat.

\section{Aktor dan Peran dalam \\ Pembentukan Kabupaten Bandung Barat}

\section{Sikap Dua Kaki Birokrat, Menolak Namun Mendanai Proses pemekaran}

Birokrat merupakan salah satu aktor yang berperan dalam proses pembentukan Kabupaten Bandung Barat, tidak dipungkiri bahwa birokrat memiliki peranan yang cukup signifikan melalui dukungan yang diberikannya kepada KPKBB sebagai kelompok masyarakat yang mengas-

57. Koran Berita Pasundan, terbit pada tahun ke IV; 12-19 Januari 2004. 
pirasikan pembentukan Kabupaten Bandung Barat kepada pemerintah. Meskipun dipermukaan para birokrat menolak aspirasi pembentukan Kabupaten Bandung Barat karena harus mengikuti arahan atau keinginan Bupati Bandung yang menolak keras pembentukan Kabupaten Bandung Barat ini, namun di sisi lain birokrat juga menampilkan sisi mendukung pemekaran. Hal tersebut jelas karena birokrat memiliki kepentingan yang ingin dicapai.

Oleh sebab itu, melihat rangkaian gerak birokrat dan diakhiri dengan lobby atau intervensi kepada bupati untuk mendapatkan jabatan, jelas terdapat kepentingan dari birokrat di Kabupaten Bandung maupun di Kabupaten Bandung Barat untuk mendapatkan jabatan sebagai salah satu tujuan mereka dalam pembentukan Kabuaten Bandung Barat.

Beberapa kalangan birokrat di Kabupaten Bandung mendukung pembentukan Kabupaten Bandung Barat dimana salah satu bentuk dukungannya adalah mendorong langkah KPKBB untuk mewujudkan pembentukan Kabupaten Bandung Barat. Dukungan mereka tidak ditunjukan secara terbuka namun dengan dukungan dana yang mereka gelontorkan kepada aktor yang menjadi kelompok kepentingan dan kelompok penekan pemerintah agar pembentukan Kabupaten Bandung Barat ini segera dilakukan.
Sumber pendanaan KPKBB selain berasal dari masyarakat, juga berasal dari birokrat di lingkungan Pemerintah Kabupaten Bandung. Menurut Ade Ratmaja bahwa KPKBB didukung oleh masyarakat termasuk dukungan dalam bentuk finansial, salah satu yang dijelaskan adalah sumbangan dari setiap camat yang mendukung "dari belakang" rencana pemekaran ini. Adanya aliran dana ini cukup menjelaskan bahwa KPKBB digunakan sebagai kendaraan bagi sebagian aktor untuk kepentingan tertentu.

Oleh sebab itu bisa disimpulkan bahwa ada keterkaitan antara perjuangan KPKBB untuk mewujudkan pembentukan Kabupaten Bandung Barat, dengan dukungan birokrat yang membentuk kepentingan jabatan. KPKBB mendapatkan suntikan "amunisi" berupa sumbangan dana untuk kegiatan operasional mereka, sementara itu birokrat di Kabupaten Bandung mempunyai peluang untuk mengakses jabatan yang lebih tinggi seiring dengan lahirnya Bandung Barat sebagai daerah otonom baru di Provinsi Jawa Barat.

\section{Kelompok Menolak Pembentukan Kabupaten Bandung Barat}

Sementara itu masyarakat yang tidak setuju terhadap pemekaran diantaranya adalah mereka yang mengatasnamakan diri mereka sebagai Forum 14 Kecamatan (F14), mereka adalah kelompok yang mendekla- 
rasikan ketidaksetujuan mereka terhadap pembentukan Kabupaten Bandung Barat. Sikap mereka dilatarbelakangi oleh alasan bahwa pembentukan Kabupaten Bandung Barat bukan merupakan solusi terhadap masalah yang saat itu ada di Kabupaten Bandung, masalah yang ada cukup diselesaikan dengan strategi selain pemekaran.

Forum 14 Kecamatan (F14) ini menjelaskan bahwa pemekaran belum perlu dilakukan karena pelayanan yang diberikan pemerintah kepada masyarakat sudah tepat hanya yang belum terlaksana adalah optimalisasi perannya saja, terlebih setelah adanya pelimpahan kewenangan oleh bupati kepada camat berdasar Keputusan Bupati Nomor 21 Tahun 2001. Pernyataan ini disampaikan secara tertulis oleh tokoh masyarakat dari Kecamatan Cililin kepada Ketua DPRD dan Bupati Bandung pada tanggal 31 maret 2003..$^{58}$

Forum 14 Kecamatan (F14) menyampaikan kepada bupati dengan mengirimkan surat pada tanggal 6 Mei tahun 2003 yang menyatakan bahwa wacana pemekaran KBB merupakan hal yang sangat terburuburu dan mengabaikan dampak negatif yang akan diterima masyarakat ${ }^{59}$. Salah satu usulan dari Forum 14 Kecamatan (F14) ini adalah menolak setiap usulan pemekaran yang dilakukan oleh sebagian masyarakat sebelum infrastruktur dan indikator sebagai prasyarat pemekaran bisa terpenuhi terutama pelayanan dan kesejahteraan masyarakat. ${ }^{60}$

Pemekaran sejatinya ditujukan karena melihat permasalahan di masyarakat terutama kondisi pembangunan dan kesejahteraan yang tidak baik sehingga harus dilakukan pemekaran dengan tujuan meningkatkan efektifitas dan efisiensi penyelenggaraan pemerintahan. Jika Forum 14 Kecamatan (F14) baru menyetujui pemekaran ketika kesejahteraan masyarakat dan infrastruktur sudah bagus, maka sejatinya tidak perlu dilakukan pemekaran.

Forum 14 Kecamatan (F14) menduga bahwa ada kepentingan politik dibalik arus kuat yang menuntut pemekaran Kabupaten Bandung ini, oleh sebab itu Forum 14 Kecamatan (F14) ini dengan tegas

58. Op. Cit. hal 34

59. ibid

60. ibid 
menolak pemekaran Kabupaten Bandung, karena jika landasan aspirasi pemekaran adalah kepentingan politik, hal tersebut tidak akan mendatangkan kebaikan untuk Kabupaten Bandung termasuk untuk Bandung Barat. Pemekaran Kabupaten Bandung hanya akan menguntungkan sebagian kecil kelompok saja sehingga masyarakat umum terabaikan.

Kelompok yang tidak setuju terhadap pemekaran daerah selanjutnya menjelaskan bahwa untuk menyelesaikan masalah yang ada di Kabupaten Bandung seharusnya bukan dengan pemekaran daerah, namun cukup dengan mendukung program dan kebijakan Pemerintah Kabupaten Bandung yang sedang dilakukan saja, serta meningkatkan rentang kendali pemerintah terhadap daerah kewenangannya.

Namun karena kuatnya arus aspirasi dari masyarakat terkait usulan pemekaran Kabupaten Bandung, maka pada tahun 2006 pemekaran Kabupaten Bandung berhasil dilaksanakan setelah melewati perjalanan yang cukup lama yaitu dari tahun 1999, tepatnya ketika otonomi daerah di Indonesia diberlakukan.

\section{Media Massa dalam Pembangunan Opini Publik}

Media memiliki peran yang sangat signifikan dalam sebuah proses agenda setting, hal ini karena media memiliki kekuatan yang cukup besar dalam sebuah proses pembangunan opini publik. Dengan bergeraknya suatu media tertentu, akan memberikan pengaruh yang sangat berarti kepada masyarakat luas, termasuk memiliki dampak yang sangat besar bagi pemerintah sebagai pihak yang berwenang mengambil kebijakan publik.

Peran media dalam proses pembentukan Kabupaten Bandung Barat dinilai sangat signifikan dan memiliki kecenderungan mendukung proses pembentukan Kabupaten Bandung Barat, dengan cirinya adalah cenderung memuat berita yang mendukung dilakukannya pembentukan Kabupaten Bandung Barat serta banyak memuat argumentasi tokohtokoh yang mendukung pembentukan Kabupaten Bandung Barat.

Dilihat dari jumlah berita yang beredar terkait proses pembentukan Kabupaten Bandung Barat, setidaknya ada 65 pemberitaan yang tersebar di berbagai media massa dengan konten yang mendukung proses pembentukan Kabupaten Bandung Barat. Galamedia dan Pikiran Rakyat menjadi media massa yang sangat intens memberitakan terkait proses pembentukan Kabupaten Bandung Barat. Selama kurun waktu tahun 2004 sampai dengan tahun 2006, Galamedia setidaknya memuat sebanyak 24 berita. Sementara itu, Pikiran Rakyat dalam kurun waktu tahun 2004 sampai dengan tahun 2006 juga memuat sebanyak 24 berita dengan kecen- 
derungan mendukung proses pembentukan Kabupaten Bandung Barat. ${ }^{61}$

Oleh sebab itu bisa dikatakan bahwa media massa memiliki peran yang signifikan dalam proses pembentukan Kabupaten Bandung Barat, hal tersebut karena media massa terutama Pikiran Rakyat dan Galamedia memiliki kecenderungan mendukung proses pembentukan Kabupaten Bandung Barat dengan cara memuat berita-berita maupun opini yang menyatakan Kabupaten Bandung Barat memang seharusnya di bentuk.

\section{Respon Pemerintah Kabupaten Bandung}

Aspirasi pembentukan Kabupaten Bandung Barat rupanya sangat keras dilakukan oleh masyarakat yang mendukung pembentukan Kabupaten Bandung Barat, berbagai upaya dilakukan dari mulai unjuk rasa hingga lobby politik kepada DPRD, sehingga isu pembentukan Kabupaten Bandung Barat ini disikapi oleh Pemerintah Kabupaten Bandung dengan menerbitkan Surat Keputusan No. 135/Kep.85-Binpenum/2004 tentang pembentukan Tim Teknis Penataan Wilayah Kabupaten Bandung.

Respon pemerintah Kabupaten Bandung ini mejadi titik selanjutnya dimana usulan pembentukan Kabupaten Bandung Barat memasuki tahap pembahasan di level pemerintah dimana hasil kajian akademis, proses administrasi dan proses politik akan menentukan apakah pembentukan Kabupaten Bandung Barat akan di bahas dan dijadikan sebagai alternatif kebijakan atau tidak.

Berikut adalah identifikasi terhadap aktor dan peranannya dalam proses pembentukan Kabupaten Bandung Barat:

61. Kliping berupa kumpulan berita di media massa terkait pembentukan Kabupaten Bandung Barat, kliping disusun oleh KPKBB pada tahun 2006. 
Tabel 2. Aktor dan Perannya dalam Pembentukan Kabupaten Bandung Barat

\begin{tabular}{|c|c|c|}
\hline No & Aktor & Peran \\
\hline 1 & Masyarakat & $\begin{array}{l}\text { Masyarakat dalam pemekaran ini sebagai individu- } \\
\text { individu yang bersama-sama mengaspirasikan } \\
\text { kehendaknya kepada pemerintah serta mendukung } \\
\text { upaya pemekaran Kabupaten Bandung. Peran } \\
\text { masyarakat terlihat sepertipadasaat aksi demonstrasi, } \\
\text { forum dan lain sebagainya. }\end{array}$ \\
\hline 2 & LSM & $\begin{array}{l}\text { LSM dalam pemekaran ini berperan sebagai } \\
\text { kelompokyang menjadi jembatan masyarakat kepada } \\
\text { pemerintah terkait dengan adanya permasalahan } \\
\text { yang ada di masyarakat dan juga menjadi kelompok } \\
\text { yang mewakili masyarakat untuk menyuarakan } \\
\text { aspirasinya terkait pemekaran Kabupaten Bandung. } \\
\text { LSM juga menjadi kelompok penekan kepada } \\
\text { pemerintah ketika upaya untukmelakukan pemekaran } \\
\text { ini tidak mendapatkan penolakan dari pemerintah } \\
\text { sebagai pemilik kewenangan. }\end{array}$ \\
\hline 3 & KРКBB & $\begin{array}{l}\text { KPKBB dalam perjalanan pembentukan Kabupaten } \\
\text { Bandung Barat mempunyai peran yang cukup besar, } \\
\text { KPKBB yang menjadi pemersatu semua LSM di } \\
\text { Kabupaten Bandung dan juga unsur yang mendukung } \\
\text { pemekaran ini menjadi Komite yang mewakili semua } \\
\text { unsur masyarakat dalam berkomunikasi dengan } \\
\text { pemerintah, melakukan upaya upaya legal untuk } \\
\text { mengupayakan terbentuknya Kabupaten Bandung } \\
\text { Barat, Seperti melakukan audiensi, rapat hingga } \\
\text { memobilisasi masa untuk melakukan demonstrasi. } \\
\text { KPKBB dalam menjalankan fungsinya juga menjadi } \\
\text { tim yang mencari dan menyediakan data kondisi } \\
\text { Kabupaten Bandung bagian barat sehingga usulan } \\
\text { pemekaran ini menjadi layak untuk dilakukan karena } \\
\text { telah didukung dengan data dan fakta. }\end{array}$ \\
\hline 4 & Pemerintah & $\begin{array}{l}\text { Pemerintah dalam pembentukan Kabupaten Bandung } \\
\text { Barat ini berperan sebagai pihak yang memfasilitasi } \\
\text { aspirasi masyarakat, melakukan penelitian, kajian } \\
\text { hingga membuat kebijakan pemekaran wilayah. } \\
\text { Dalam kenyataannya, pemerintah juga berperan } \\
\text { sebagai pihak yang tidak menyetujui pemekaran } \\
\text { daerah karena beberapa kepentingan yang ingin } \\
\text { dipertahankannya. }\end{array}$ \\
\hline
\end{tabular}




\begin{tabular}{|c|c|c|}
\hline 5 & DPRD & $\begin{array}{l}\text { DPRD Kabupaten Bandung berperan sebagai lembaga } \\
\text { yang mewadahi aspirasi masyarakat serta melakukan } \\
\text { pengkajian akan layak atau tidaknya dilakukan } \\
\text { pembentukan Kabupaten Bandung Barat. Melakukan } \\
\text { proses politik untuk mewujudkan pemekaran dan } \\
\text { membuat peraturan yang sah sehingga pembentukan } \\
\text { Kabupaten Bandung Barat dikatakan sah secara } \\
\text { hukum. }\end{array}$ \\
\hline 6 & $\begin{array}{c}\text { Tim } \\
\text { Konsorsium }\end{array}$ & $\begin{array}{l}\text { Tim Konsorsium berfungsi sebagai lembaga akademis } \\
\text { yang mengkaji penataan wilayah. Tim Konsorsium } \\
\text { ini membahas kondisi Kabupaten Bandung dari } \\
\text { semua aspek, baik di wilayah timur, tengah maupun } \\
\text { barat. Sehingga melalui Tim Konsorsium ini bisa } \\
\text { didapatkan data dan fakta yang relevan sebagai bahan } \\
\text { bagi pemerintah untuk membuat kebijakan, termasuk } \\
\text { menerima atau menolak aspirasi pembentukan } \\
\text { Kabupaten Bandung Barat. } \\
\text { Tim Konsorsium juga menjadi lembaga yang } \\
\text { berfungsi memberikan rekomendasi terkait kebijakan } \\
\text { termasuk perencanaan pembangunan dan tata kelola } \\
\text { ruang pasca pemekaran dilakukan, baik penataan } \\
\text { wilayah di Kabupaten Bandung maupun penataan } \\
\text { wilayah di Kabupaten Bandung Barat. }\end{array}$ \\
\hline 7 & Media Massa & $\begin{array}{l}\text { Media massa berfungsi sebagai aktor yang } \\
\text { mengangkat isu pemekaran ini ke ruang publik, } \\
\text { sehingga pemekaran ini bisa diketahui oleh } \\
\text { masyarakat luas. Selian itu media massa menjadi } \\
\text { sarana bagi berbagai pihak untuk menyuarakan } \\
\text { pendapatnya terkait pemekaran Kabupaten Bandung, } \\
\text { baik dari sisi kelayakan, kondisi wilayah hingga sisi } \\
\text { politis. } \\
\text { Mediamassajugaberfungsisebagai saranakomunikasi } \\
\text { antara semua pihak, termasuk antara pemerintah dan } \\
\text { juga masyarakat Kabupaten Bandung. }\end{array}$ \\
\hline 8 & $\begin{array}{c}\text { Kelompok } \\
\text { Kontra }\end{array}$ & $\begin{array}{l}\text { Kelompok kontra dalam hal ini memiliki fungsi } \\
\text { sebagai penyeimbang dari kelompok arus proterhadap } \\
\text { pemekaran Kabupaten Bandung. Kelompok Kontra } \\
\text { dalam menjalankan perannya mampu menyajikan } \\
\text { argumentasi yang cukup kuat sehingga menambah } \\
\text { dinamika perjalanan pembentukan Kabupaten } \\
\text { Bandung Barat, baik melalui tulisan maupun melalui } \\
\text { forum resmi yang diadakan oleh mereka sebagai } \\
\text { kelompok kontra. }\end{array}$ \\
\hline
\end{tabular}




\begin{tabular}{|c|c|l|}
\hline 9 & \multicolumn{1}{|c|}{ Tim yang } \\
Tersisihkan & $\begin{array}{l}\text { Tim yang Tersisihkan merupakan aktor intelektual } \\
\text { yang memiliki peran sebagai otak dari rencana } \\
\text { pembentukan Kabupaten Bandung Barat, sekaligus } \\
\text { sebagai sumber dana operasional bagi aktor lapangan } \\
\text { yang terlibat dalam proses pembentukan Kabupaten } \\
\text { Bandung Barat. Semua strategi yang dilakukan } \\
\text { dilapangan pada kenyataannya menjadi strategi yang } \\
\text { telah disusun oleh tim ini. Disebut sebagai tim yang } \\
\text { tersisihkan karena mereka adalah aktor utama namun } \\
\text { pasca Bandung Barat terbentuk mereka terkalahkan } \\
\text { oleh kekuatan politik lain dan tidak mendapatkan } \\
\text { keuntungan seperti yang mereka inginkan. }\end{array}$ \\
\hline 10 & Tjatja Kuswara \\
& $\begin{array}{l}\text { Orang yang berperan sebagai Penjabat Bupati } \\
\text { Kabupaten Bandung Barat, yang menjabat selama 1 } \\
\text { tahun 3 bulan, dimana beliau direkomendasikan oleh } \\
\text { Gubernur Jawa Barat dan disetujui oleh Mendagri } \\
\text { atas nama presiden. }\end{array}$ \\
\hline
\end{tabular}

\section{KESIMPULAN}

Pembentukan Kabupaten Bandung Barat secara resmi terbentuk pada tahun 2007 melalui UndangUndang Nomor 12 tahun 2007 Tentang Pembentukan Kabupaten Bandung Barat, adanya kebijakan ini memang layak untuk dilakukan mengingat kondisi kesejahteraan masyarakat, luas daerah dan juga kemampuan pemerintahan Kabupaten Bandung dalam menjalankan tugas dan fungsinya yang dirasa tidak maksimal.

Namun dalam proses berjalannya pembentukan Kabupaten Bandung Barat tersebut, muncul berbagai agenda dan kepentingan yang dibawa oleh masing-masing elit, baik itu elit birokrat, politisi, kelompok masyarakat hingga pemilik modal. Mereka berlomba-lomba untuk mendapatkan keuntungan bagi mereka masingmasing seperti jabatan dan juga penguasaan proyek-proyek pembangunan. Adanya agenda kepentingan ini menjadikan pembentukan Kabupaten Bandung Barat sebagai lahan politis dengan tujuan mereka yang justru dapat mendistorsi esensi dari sebuah usaha pembentukan daerah otonom baru, yaitu untuk meningkatkan kesejahteraan masyarakat.

Pembentukan Kabupaten Bandung Barat yang begitu politis membawa dampak signifikan bagi kondisi Kabupaten Bandung Barat pasca terbentuk termasuk dalam ranah pemerintahan. Adanya keinginan mendapatkan jabatan di Kabupaten Bandung Barat bagi sebagian elit birokrat menjadi kenyataan yang 
harus dihadapi pemerintah, yang jika tidak disikapi dengan baik maka akan melahirkan korupsi, kolusi dan bentuk penyimpangan lainnya dalam bentuk yang lebih massif. Selain itu, pemburu rente atau rent seeker yang menyasar proyek-proyek pemerintah juga banyak terjadi dan melibatkan orangorang yang mempunyai catatan keterlibatan dalam proses pembentukan Kabupaten Bandung Barat, ini menunjukan ada keuntungan ekonomi yang diburu oleh mereka sebagaimana hal tersebut juga menjadi salah satu alasan keterlibatan mereka dalam pembentukan Kabupaten Bandung Barat. Efek dari hal ini memang sangat besar, terjadi jual beli proyek dan juga penyelewengan yang merugikan pemerintah dan rakyat pada umumnya, oleh sebab itu dalam kurun waktu 9 tahun sejak Kabupaten Bandung Barat terbentuk ternyata menyisakan beberapa kasus penyelewengan yang sampai saat ini belum juga tuntas.

Patut kita kaji kembali sebuah proses pembentukan daerah otonom baru terutama pasca terbentuknya, baik dari sisi pemerintahan, pembangunan hingga kesejahteraan masyarakat. Apakah ada korelasi pembentukan daerah otonom baru terhadap peningkatan kesejahteraan masyarakat secara signifikan sehingga pembentukan daerah otonom baru dikatakan sebagai solusi terbaik, atau justru pembentukan daerah otonom baru hanya permainan elit yang ingin memenuhi ambisi mendapatkan kekuasaan dan kekayaan hingga kesejahteraan masyarakat yang menjadi fokus utama terabaikan. Nampaknya hal ini harus di kaji lebih lanjut dan menjadi sebuah hipotesis yang menarik untuk dicari jawabannya melalui rangkaian penelitian lebih lanjut.

\section{SARAN}

Pembentukan Kabupaten Bandung Barat dilakukan dengan penuh dinamika. Maka berdasarkan hal tersebut ada beberapa saran terkait pembentukan wilayah otonom baru. Beberapa saran tersebut adalah sebagai berikut:

1. Pemerintah Lebih Mengefektifkan Kinerjanya Hingga Pelosok Daerah

2. Masyarakat harus lebih selektif dalam menghadapi mobilisasi tertentu

3. Masyarakat Aktif Mendorong Kinerja dan Rencana Pemerintah

4. Aktor LSM Mampu Memberikan Pendidikan Kepada Masyarakat

5. Pemerintah Menyiapkan Sejak Awal Urusan Pemerintahan dan Asset Daerah 


\section{DAFTAR PUSTAKA}

Ambardi, $\quad 2009$. Mengungkap Politik Kartel Studi Tentang Sistem Kepartaian Di Indonesia Era Reformasi. Jakarta: Kepustakaan Populer Gramedia Arikunto,

Suharsimi. 2006. Prosedur Penelitian, Suatu Pendekatan Pendek. Jakarta: PT Rineka Cipta.

Kencana, Inu, 2011. Ilmu Administrasi Publik, Jakarta : Bandung.

Kencana, Inu, 2011. Sistem Pemerintahan Indonesia. Jakarta: Rineka Cipta Kencana, Inu. 2003. Ilmu Pemerintahan. Bandung: Mandar Maju Moleong,

Lexy, J. 2002. Metodologi Penelitian Kualitatif. Bandung: Remaja Rosda Karya.

Nazir, Muhammad. 1998. Metode Penelitian. Jakarta: Grafindo.

Rasyid, M Ryaas. 2000. Makna Pemerintahan: Tinjauan Dari Segi Etika Dan Kepemimpinan. Jakarta: Mutiara Sumber Widya.

Ratmadja, Ade, Dkk. 2006. Perjalanan Pembentukan Kabupaten Bandung Barat Menjadi Daerah Otonom Di Provinsi Jawa Barat. Bandung Barat: Komite Pembentukan Kabupaten Bandung Barat (KPKBB).

Satori Djam'an Dan Komariah Aan, 2009. Metode Penelitian Kualitatif. Bandung: Alfabeta

Siagian, Sondang, P. 1996. Filsafat Administrasi. Jakarta: PT Grasindo.
Simarmata, Salvatore, 2014. Media Dan Politik. Jakarta: Buku Obor

Subarsono, Ag. 2009 Analisis Kebijakan Publik. Yogyakarta: Pustaka Pelajar

Sugiyono. 2011. Metode Penelitian Kuantitatif Kualitatif Dan $R \& D$. Bandung: Alfabeta. Syafiie Inu Kencana, 2006. Ilmu Administrasi Publik. Rineka Cipta: Jakarta

Widodo, Joko, 2009. Analisis Kebijakan Publik. Bayumedia: Malang

Undang-Undang nomor 12 tahun 2007 Tentang Pembentukan Kabupaten Bandung Barat

Keputusan Bupati No 21 tahun 2001 tentang Pelimpahan Beberapa Kewenangan Pemerintah Daerah kepada Pemerintah Kecamatan

Surat Keputusan No. 135/Kep.85Binpenum/2004 tentang Pembentukan Tim Teknis Penataan Wilayah Kabupaten Bandung.

Koran Berita Pasundan Nomor 24 tahun ke IV 12-19 Januari 2004 dengan judul "5000 Rakyat Bandung Tuntut "Merdeka"

Koran Galamedia, terbit pada hari kamis 6 April 2006 dengan judul "Menggali Potensi yang Terpendam.

Koran Pikiran Rakyat terbit pada selasa 3 Oktober 2006 dengan judul "KPKBB Usulkan Panji Pj Bupati Bandung Barat" halaman 9.

Pikiran Rakyat terbit 10 Juni 2004 dengan judul "Pemekaran, Jangan Menyengsarakan Rakyat. 